\title{
Valuing ecosystem benefits in a dynamic world
}

\author{
Sarah Cornell* \\ QUEST, Department of Earth Sciences, University of Bristol, Queens Road, Bristol BS8 1 RJ, UK
}

\begin{abstract}
The concept of ecosystem services is proliferating rapidly in research and policy worldwide and holds strong appeal as a bridging concept between the natural world and society. In applying the concept, we should remain alert to some 'health warnings' from previous experience in environmental economics. (1) The ecosystem services concept involves a narrowing of focus onto the money value of ecosystems. Researchers and practitioners should reflect on past efforts in integrative benefits analysis. (2) There can be a conceptual disconnection of value from function, particularly when there is a reliance on benefits transfer, yet the value of ecosystem services is conditional on a well-functioning whole ecosystem. (3) The problem of data paucity is stark. While inadequate data and the resulting uncertainty are ubiquitous problems in environmental decision-making, the powerful simplicity of one number - the estimated monetary value of a given ecosystem service-may mean that more nuanced precautionary considerations that normally apply in uncertain contexts are bypassed. New challenges arise because values (determined in the past) are applied to a changing and already resource-depleted world. Here I highlight the non-stationary nature of trends, the extent to which models are trusted and its role in uncertainty and risk, and the need for in-depth interdisciplinary study. Some organisations have already entered into these meta-debates; examples are the joint Environment Agency/Quantifying and Understanding the Earth System (EA/QUEST) project on uplands and the Economic and Social Research Council-Natural Environment Research Council (ESRC-NERC) interdisciplinary workshop series in the UK, and, internationally, the Ecosystem Services Partnership. It is important that this debate is maintained and extended.
\end{abstract}

KEY WORDS: Ecosystem services · Sustainability · Environmental management · Valuation

\section{THE RISE AND RISE OF ECOSYSTEM SERVICES}

The rapid penetration of the concept of ecosystem services in research and policy is largely driven by the urge to tackle unsustainable economic drivers of environmental degradation. The scale and seriousness of biodiversity loss and climate change are now fully recognised (MA 2005, IPCC 2007, UNEP 2007), and both are a consequence of human over-exploitation of natural resources (UNDP 2007). The present study is a critical analysis of this contemporary socio-environmental research and policy issue.

Ehrlich \& Mooney (1983) conceptualised ecosystem services - the benefits to humans that well-functioning ecosystems provide-as a way to draw attention to the fact that there may be no substitutes for living re- sources, unlike the other economic resources on which we depend. They were calling for better understanding of ecosystem structure and function at least as much as warning about environmental degradation. Within a decade, the concept had been brought into the discourse of 'natural capital' and sustainability (Costanza \& Daly 1992, Ehrlich \& Ehrlich 1992), shifting the research focus to valuations and trade-offs of ecosystem goods and services. Following Brown \& MacLeod's (1996) study that highlighted the concept of nature in terms of its benefits to human society (stressing the importance of this for environmental and natural resource management), a policy-oriented research community flourished. The International Society for Ecological Economics was founded in 1989, institutionalising this new field of study. New tools and method- 
ologies were explored within an ethos of integration of ecology and economics (Daily 1997). Conventional economics also trained its sights on environmental issues (e.g. Stern 1999, Fromm 2000, Pearce 2002). Pearce et al. (1996) highlighted the problem that conventional economics generally treats unvalued environmental assets as if they had a price of zero, resulting in over-consumption. They propounded the view that 'cost-benefit thinking would greatly enhance the chances of conservation competing with development on equal terms...'.

The policy world's attention turned sharply to ecosystem services following the publication in 2005 of the Millennium Ecosystem Assessment (MA 2005). The concerted voices of over a thousand international academic experts told an unalloyed story of environmental degradation and biodiversity loss, firmly framed in terms of the consequences for human well-being. The MA did not, however, quantify these trends and consequences in economic terms. Data paucity was one reason. In 2007, following a meeting of the environment ministers of the G8 countries and the top 5 emerging economies (India, China, Mexico, Brazil and South Africa), the so-called 'Potsdam Initiative' for biodiversity was launched. Among its activities is a global study to 'initiate the process of analysing the global economic benefit of biological diversity, the costs of the loss of biodiversity and the failure to take protective measures versus the costs of effective conservation'. The aforementioned study, 'The Economics of Ecosystems and Biodiversity' (known as TEEB) has now produced interim and summary policy reports (Sukhdev et al. 2008, ten Brink et al. 2009), with further targeted reports planned for 2010. Along with this study, the Potsdam Initiative commits all of its partners to a deeper embedding of biodiversity issues in development cooperation and to 'approach the financial sector' to include (in its project financing) biodiversity as an element of its social and environmental risk assessment and management (building on the corporate voluntarist Equator Principles [EPFI 2006] that apply to capital projects of $>\$ 10$ million, for example). Thus, economic-and specifically monetary - valuation has now been given a pivotal role in ecosystem conservation and management.

In the UK, the ecosystem services concept has taken firm hold. The Department of Environment, Food and Rural Affairs (Defra) has adopted an ecosystem approach that 'ensures the value of ecosystem services is fully reflected in decision-making' (Defra 2007). Given the shortage of empirical socio-economic data to guide this decision-making, there has been a strong 'policy pull' for research. Defra commissioned a series of research projects from 2006 onwards (www.defra. gov.uk/wildlife-pets/policy/natural-environ/research. $\mathrm{htm}$ ), to provide an evidence base for environmental assessment, trends and valuation. The Environment Agency, Natural England, and many other organizations are also investing in interdisciplinary research. In the context of the UK uplands, many of these organizations work closely together, through the Moors for the Future partnership (www.moorsforthefuture.org.uk) and other kinds of collaboration. This research extends the UK's comparatively rich body of policy-oriented research in environmental economics and in integrative natural resource management; insights - and potential concerns - stemming from this research and management experience can be drawn for application of the ecosystem services concept.

\section{LESSONS FROM OLD CHALLENGES}

\subsection{The tyranny of money}

There is ambiguity in the literature about the monetary valuation of ecosystem services. The concept itself does not necessarily involve a narrowing of focus onto the money value of ecosystems. The European Environment Agency, for instance, states that the goal of its current ecosystem accounting initiative is to 'measure the gap between the reality of ecosystem integrity and the [policy] objectives... and then to calculate the additional maintenance and restoration costs of meeting these objectives'. In contrast, 'policy pulls' like Defra's Ecosystem Approach, the Potsdam Initiative and the TEEB shift the emphasis of research towards monetary valuation rather than other more integrative or plural assessments of ecosystem value.

Monetary values are underestimates of the total value or importance of ecosystems. Gren et al. (1994), testing various environmental economic approaches for valuing wetlands, concluded robustly that only part of their value can be captured in money terms. Most of the text of the landmark Costanza et al. (1997) article on the value of nature explains why the suite of methods they picked were likely to err on the conservative side of value. Turner (1992) explained more formally how the total ecosystem value is greater than the total economic value. Recently, a debate has emerged that is often taken as an arcane economists' argument about semantics: Is there a difference between ecosystem services and ecosystem benefits? Given that the working definition of 'ecosystem services' that is generally accepted by researchers and policy makers is something akin to of the MA (2005) definition, 'the benefits people obtain from ecosystems', we can consider that the terms are interchangeable (as Costanza 2008 proposes). For other economists (Boyd \& Banzhaf 2007, Fisher \& Turner 2008), whose goal is to 'price' the benefits (that is, ob- 
tain a money value in terms of utilisation, direct or indirect), the terms need to be distinct. Economic values can be determined for 'benefits', that is, perceptible changes in human well-being. Ecosystem 'services', then, are the subset of ecological functionings that people appreciate in some way. Without joining in that debate, the shared corollary of the views on both sides is that the money values of ecosystem services are not the true values. Realised benefits may be valued, but the rest is not. Thus, in relying upon money valuations of ecosystem services (or benefits, or whatever), we risk applying part-values to the whole thing.

This is old information, of course. The challenges of linking value with a money 'price' may be too much like moral philosophy rather than science or economics, but they matter. Kant (1998, p 41-43) argued that things like nature, unsubstitutable and untradeable, should not be given a market price, but 'be cognized as dignity' and put 'infinitely above all price, with which it cannot be brought into comparison or competition at all without, as it were, assaulting its holiness'. (Pearce et al. [1996] allude to the regrettable fact that infinite value is indistinguishable from zero value in the real world of economic decision-making.) Von Mises (1996) emphasised that money plays an intermediary role in what is ultimately an exchange of some kind of economic goods against other such goods. He argued that economists misconstrued economic valuation, taking it 'for a category of all human action' rather than regarding it as acting under special conditions, namely the exchange market. Daly (2009) explains how a 'dollar's worth' may be a working unit of value, but 'a dollar' itself is not-there must be a connection from money (a conceptual abstraction, or contract) to the physical world.

There are many valuation methods for environmental goods and services (outlined concisely in Raffaelli et al. [2009], which also includes a vignette on the utilitarian framing of ecosystem services). Some consider them to be incommensurable (e.g. Sinden 2004), but, in any case, the values from these methods should not be regarded as aggregable or interchangeable (Jacobs [2008] reiterates this bluntly).

Nevertheless, policy has taken the pragmatic view for many years now that monetary valuations of ecosystems may not be true, but they are true enough to be added or subtracted from other costs and benefits, informing the difficult spending decisions that often have to be made about trade-offs in resource allocation to protect and manage natural resources.

\subsubsection{What problems arise?}

Pragmatism is a vulnerable position. First, it can be criticised for the degree of subjectivity in choosing a 'price' to sway an environmental resource decision. For instance, knowing the market price of horticultural peat (UK sales estimated at $£ 30$ million $\mathrm{yr}^{-1}$ in Jacobs [2008]) might set environmental managers a guideline for the desired total value of other peatland ecosystem services, similar to the starting-bid bias (Boyle et al. 1985, Bateman et al. 1995) in contingent valuation. Secondly, a money value, once defined, does not necessarily remain static. Money is not neutral and purchasing power does not change for all goods and services uniformly (von Mises 1996). In the UK uplands context, the (market) price of peat for fuel and horticulture might be expected to rise if supplies become scarcer or are restricted (although in practice, price elasticity of demand for peat seems to be low: people are buying coir-based composts instead). But changing demand for peat is not solely controlled by the price mechanism. Knowledge about its ecological importance changes people's perception of its value, and this interacts in complicated ways with the market price for peat.

There are risks to be aware of. First, an over-reliance on costs and benefits framed in money terms can result in social and environmental inequities (Lucas et al. 2004, Sinden 2004, Walker 2007). Also, the mismatch in meaning and understanding of the terms ecosystem services, values, benefits, and so on, even as they become common parlance, can mean that one group of people are concerned with the whole, while others are concerned with the economically 'value-able' part. The multi-disciplinary community engaging in ecosystem services as a research and policy concept may inadvertently be talking and working at cross-purposes. In the UK uplands context, Defra and the Peat Partnership Project mostly take what Jacobs (2008) terms the CSERGE $^{1}$ approach, of distinguishing services from benefits defined in money terms; however, from meetings and literature, it is clear that many people consider a broader meaning — for them 'taking ecosystem services into account' means attempting to consider the interplay of humans and the natural environment more holistically.

\subsubsection{What are the alternatives?}

Although ecosystem services as a concept might be relatively new, integrative research linking ecosystem analysis, economics and various aspects of social inquiry is not. The apparent narrowing of policy focus on

\footnotetext{
${ }^{1}$ CSERGE is the Centre for Social and Economic Research on the Global Environment at the University of East Anglia. It is one of the longest established environmental economics groups in the UK and is a leading centre for methodological development and valuation
} 
money values does not mean that this past research is no longer useful.

Since the late 1980s, there has been a considerable European research investment in interdisciplinary, integrative methods to support environmental decision-making. This was driven initially by the growing availability of technologies to inform spatial planning (e.g. Earth observation data, GIS tools) and also by the development of sustainability policy, particularly Agenda 21, which enshrined citizen involvement in environmental and development decision-making (cordis.europa.eu/fp5/home.html). In areas like water resources and coastal zone management, where European-funded research programmes spread over consecutive Framework Programmes, assessment and modelling of ecosystem structures and processes were combined with economic valuations and participatory engagement with communities and decision-makers. Initial efforts were inelegant: typically each contributing discipline community worked independently, leaving 'integration' to the end. Unsurprisingly, these early, chunkily bolted-together Decision Support Systems were not taken up enthusiastically by decision-makers.

Nevertheless, the transdisciplinary research/stakeholder dialogues that began were vitally important; the programmes delivered diverse experiments in better conceptual integration of environmental, economic and social sciences, perhaps most notably the idea of the socio-ecological system; and a large body of research developed into assessment of environmental value in more multi-dimensional ways than monetary valuation. Some techniques retain a utilitarian underpinning - multi-attribute utility theory provides methods for structured evaluation of trade-offs (e.g. Janssen \& Van Herwijnen 2006). Others deliberately avoid the scaling and weighting aspects of multi-criteria analysis, but still use some of its formalisms in a more contractarian or deliberative framework. Stirling (1997), for instance, prefers to use interactive multi-criteria mapping methods to expose and explore stakeholder conflicts and preferences.

This prior experience shows us that money does not need to be the sole metric, and that often better decisions can be made when it is not. Sagoff (2000) emphasises the need for diversity and deliberation in democratic decision-making, rather than relying on an economic reduction of the public good to some aggregate of individual welfare. Spash \& Vatn (2006) also argue that analysts should keep an expanded set of approaches in mind. The UK Sustainable Development Strategy framework (HM Government 2005) has 2 toplevel goals: living within environmental limits and ensuring a healthy and just society. In maintaining the balance of these goals, the framework emphasizes that good governance and the use of sound science are as essential as a consideration of the social and environmental costs and benefits. Turner \& Daily's (2008) framework for ecosystem services application also highlights the critical importance of inclusive and participatory governance.

\subsection{Knowing how valuable ecosystem services are}

Paucity of data is a ubiquitous challenge in environmental decision-making and a significant source of uncertainty. The challenge is summarised in the Defrafunded Eftec report (Eftec 2006), which found that most environmental policy makers deal with gaps in value information by 'informed guesswork' and by applying sensitivity analysis. The gaps in value evidence arise at all stages: there is not enough detailed environmental data to inform useful economic valuations; many types of natural environment have no monetary valuations; and, sometimes, when valuations exist, they are not accessible. Water companies, for instance, engage in valuation activity that largely remains in the grey literature and rarely reaches the wider research community. Frankly, though, there is plenty of literature to wade through. Fig. 1 shows the growth of the research output over the last $15 \mathrm{yr}$, using the ISI Web of Knowledge database. A search of 'ecosystem services' produces nearly 2000 articles, of which fewer than 300 include 'valuation'. Before the publication of the MA, the rate of increase of valuation studies was keeping pace with non-valuation studies, but now, although there has been a sharp rise in both kinds of literature, about 8 to 9 times as many articles have been published talking about ecosystem services rather than assessing and valuing them. While deliberation of new concepts is important, demand for valuations is seriously outstripping supply.

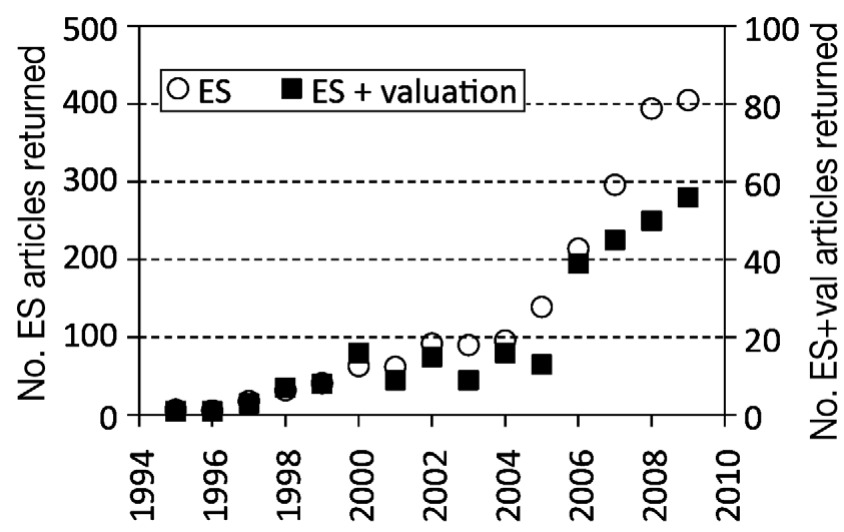

Fig. 1. Citations of ecosystem services (ES) and ecosystem services + valuation (ES + val) available on the ISI Web of Knowledge 
Policy clearly drives valuation studies. Wetlands are comparatively well studied, because the Ramsar Convention provided a focused demand for valuation studies. Coastal zones are also well studied, because of the European Demonstration Projects on integrated coastal zone management. Valuation of forest goods and services is on the ascendant now (accounting for $20 \%$ of the ISI ecosystem services + valuation articles, almost all published since the MA), because of the developing carbon market and associated sustainability dimensions in carbon management. There is very much less value information on many other ecosystems in the UK that are exploited in multiple ways and that are therefore subjected to multiple pressures, although as mentioned, UK environmental research funders have invested a considerable amount in synthesising and expanding on this information base, including Defra's 20 projects under its ecosystem approach and NERC's biodiversity and natural resources scoping studies (www.nerc.ac.uk/research/themes/tap/reports/ 2008/valuationofbiodiversity.asp). So far, most of the reports (notably, Eftec 2006, Jacobs 2008, Graves et al. 2009, Raffaelli et al. 2009) make it clear that fundamental information about ecosystem function is needed before ecosystem value can be assessed, and thus access to environmental data is a limiting factor.

Peatlands and uplands are now in the limelight because they may matter for the UK's carbon reduction commitments. The carbon market (and the Potsdam Initiative) drives the need not just to 'value' their ecosystem services but to monetise them. However, UKspecific valuations are very sparse. The United Utilities/ RSPB Sustainable Catchment Management Programme (www.unitedutilities.co.uk/SCaMPdatalibrary.htm) included a peat restoration project in the Peak District that indicated potential water treatment costs of $\sim £ 1$ million to $£ 2$ million $\mathrm{yr}^{-1}$ could be avoided across the catchment. The Jacobs (2008) review of valuation studies reported a carbon storage value for UK peatlands, using an avoided damage cost of $£ 5$ million $\mathrm{yr}^{-1}$, compared with a cultural/amenity value of $£ 65$ million $\mathrm{yr}^{-1}$ for hill-walking and revenues from peat extraction of $\sim £ 30$ million $\mathrm{yr}^{-1}$. The economic message is that existence values (or supporting and regulating values, to use the MA typology) are minor compared with exploitation and amenity values-which is not the desired outcome for anyone interested in sustaining ecosystem services, of course.

The problems are not limited to data shortage, however. Analysts are often faced with 'apple and orange' type comparisons: the carbon storage value above also includes lowland peatlands; the hill-walking figure clearly relates to generic uplands, not any particular landscape. Important questions like 'what economic benefits might be realized from the restoration of an area of peatland, open moorland or grazed fell?' cannot be resolved from the available data. A search of the international Environmental Valuation Reference Inventory (EVRI) database for UK valuation studies (which also includes grey literature) yielded little more than a dozen references (Table 1), which included meeting reports and studies that, in other contexts, might be considered subject to bias (the Ramblers' Association study of the value of walking, for instance). There are evidently more values in circulation-the SCaMP study has shown that the body of grey literature is significant, and there is a plethora of post-graduate research projects and working papers that pro-

Table 1. Literature returns from a search of the Environmental Valuation Reference Inventory (www.evri.ca, accessed May 2009) database for reports and data on UK ecosystem analysis, valuation, or ecosystem services

\begin{tabular}{|c|c|}
\hline Subject & Reference \\
\hline \multicolumn{2}{|l|}{ Ecosystem function } \\
\hline Pollinator decline & Allen-Wardell et al. (1998) \\
\hline Soil erosion & McHugh (2003) \\
\hline Air quality (national emissions data) & AEA Technology (2005) \\
\hline Carbon flux & MFTF (2007) \\
\hline \multicolumn{2}{|l|}{ Valuations } \\
\hline CBA of Somerset Levels \& Moors Environmental Sensitive Area & Garrod et al. (1994) \\
\hline Nature conservation & White \& Lovett (1999) \\
\hline Woodland and Soil conservation & Bateman \& Lovett (2000), Colombo et al. (2006) \\
\hline Wetlands & Brander et al. (2006) \\
\hline Ecosystem services-Scotland & Williams et al. (2003) \\
\hline $\begin{array}{l}\text { Ecosystem services assessment of England's woodland, } \\
\text { intertidal zone and freshwater wetlands }\end{array}$ & English Nature (2006) \\
\hline Grazing management & Bullock \& Kay (1997) \\
\hline 'Spectacular' birds & Dickie et al. (2006), for the RSPB \\
\hline Countryside access (Ridgeway National Trail) & Bennett et al. (2003) \\
\hline Walking & Christie \& Matthews (2003), for the Ramblers Association \\
\hline Danish moorland (no UK valuations in EVRI) & Boiesen et al. (2005) \\
\hline
\end{tabular}


vide data used within institutions. But it is through the peer-reviewed literature that data and methods can be critiqued and developed. It seems likely that current decisions with effects on ecosystems are being made without a systematic critical assessment of the evidence.

EVRI, an information database supported by Environment Canada, the United States Environmental Protection Agency (US EPA), Defra and other government organizations, is intended as a resource for users of the benefits transfer approach. Benefits transfer is presented as an alternative to doing new valuation research; essentially, it involves the borrowing of values estimated for other contexts. A considerable body of literature exists about the practical problems in applying estimates of externalities, that is, the costs or benefits not captured in the market price, to different contexts (Boyle \& Bergstrom 1992, Brookshire \& Neill 1992, Brouwer \& Spaninks 1999). Spash \& Vatn (2006) summarise the issues, highlighting the limited (often the lack of) validity testing that is being undertaken for applications of benefits transfer in ecosystem services valuation. Loomis \& Rosenberger (2006) are enthusiasts for benefits transfer, arguing that decision-makers should be able to deploy the 'stock of knowledge', but they also acknowledge that there are problems with validity and reliability. They suggest how study designs could be made more consistent to allow for transfer of results. However, this rigidity in study design might then suppress the range of different values that individuals express, and therefore not represent welfare robustly.

At present, there are insufficient data for sensitivity analyses of most environmental values. Methodologies and data sets for meta-analysis are developing, which should give more robust values. However, most studies pertain to wetlands, where information resources have been built up over the 40 years since the Ramsar Convention (Woodward \& Wui 2001, Brander et al. 2006, Ghermandi et al. 2008). The urgency of the application of the ecosystem services concept leaves little chance of amassing a similar body of robust knowledge for other habitats and landscapes.

Care therefore needs to be taken that the powerful simplicity of one number-the monetary value of a given ecosystem service-does not lead to the bypassing of more nuanced precautionary considerations (Stirling \& Gee 2002) that normally apply in datasparse, uncertain contexts.

\subsection{Value depends on a well-functioning ecosystem}

The value of ecosystem services depends on a wellfunctioning 'whole' ecosystem. In many circles in both research and implementation, there is an alarming conceptual blurring of the 'holistic' idea of ecosystem services - all the good things nature does for humans with the specific and context-dependent societal benefits attributed to ecosystem processes or functions. Classification for the valuation of ecosystem services involves assumptions of modularity, that is, an ability of components of the system to be disconnected and recombined. The illustrations with boxes linked with arrows that always appear in ecosystem services literature can lead to the idea that the compartmentalisation - which is undeniably useful for conceptualisation and the identification of the whole scope of the system-reflect the real world. Yet ecosystems are intricate and interdependent systems. Changing one component has knock-on effects on others (e.g. Vandermeer \& Lin 2008). Furthermore, as Raffaelli et al. (2009) explain, we should be conceptualizing ecosystems as coupled socio-ecological systems. They are not biophysical systems that provide services for a separate (or separable) social system. Ecology and Earth System Science, as disciplines, have both struggled with the idea that humans are actually in the ecosystem, a dynamic component of it, rather than detached observers. There is a strand in the ecosystem services debate that adheres to this idea, starting with Ehrlich \& Mooney (1983). But increasingly, although everyone talks about the socio-ecological system as a complex adaptive system (e.g. Anderies et al. 2004) characterised by non-linearities, thresholds, and scale-dependencies or emergence, our tendency to analyse by disassembly or reduction wins out.

The other strand of ecosystem services is an extension of the domain of economics into ecology, with a strong directedness from policy. There can be a conceptual disconnect of value from process or function, particularly when there is a reliance on benefits transfer. This strand has developed very much from the perspective of evaluating human interdependencies on our ecosystem, given our current (economic) methods, rather than seeking out new, more appropriate conceptualisations. Past experience can guide us in designing those new conceptualisations. For instance, the multi-criteria approaches mentioned before have had to develop clear operational guidelines for the classifications or criteria that they use. Obviously, the set of attributes or criteria need to give complete enough coverage of the whole issue; they also need to be practically implementable, in the sense that it must be possible to consistently measure or assess the performance of a given option against the criterion, at least in a qualitative way; and they need to be parsimonious, so there is no overlap (double-counting), nor unnecessary complication. Categories and typologies for ecosystem services are known to be problematic (e.g. Wallace 2007, Raffaelli et al. 2009) failing in at least one of these areas. 
Furthermore, as Fisher \& Turner (2008) say, types depend on context, and they evolve in use (as in Natural England's Peat Project, www.naturalengland.org.uk/ ourwork/conservation/biodiversity/englands/peat.aspx, which works with 5 classes of ecosystem services). However, ecosystem services may not need the help of taxonomists for classification. Turner \& Daily (2008) address the challenge in a tried-and-tested way, by emphasising governance-the need for real dialogue among research, policy, practice and communities to determine and manage ecosystem services.

Extending the domain of economics in this way has moral, socio-political and philosophical dimensions, but it also comes up hard against a 'scientific' issue. A better mapping of ecosystem value onto ecosystem function and process is clearly a major research priority, but we still need to know if economic benefit is being extracted by eroding or destroying the means of production. The focus of ecosystem analysis is often framed as structure, process and function, and ecosystem services assessment should obviously retain these elements. In addition, given that economics has no intrinsic endpoint to growth (Daly 2009), in this application of economics to finite ecosystems, we may also need explicitly to add the concept of 'environmental limits'.

The valuation tools of economics were designed for marginal quantities, not for decisions at or near environmental limits, although there have been 'total' valuations and inventory assessments of ecosystem services, as kinds of global or national accounts. In other words, monetary valuations are meaningful for gradual decisions, involving 'small quantities' of change. The current policy pull is for valuations to be applied to the question of how much ecosystem structure can be degraded versus how much should be guarded to ensure our life-support systems keep working, as if they were marginal exchanges. Science is currently showing us that rather than making marginal exchanges from a very big quantity of natural capital, we are taking quite large chunks from a depleting supply. In some cases, the decision to consume certain ecosystem benefits could result in the destruction of that ecosystem. Where there are risks, say, of extinction, we may be faced with a binary choice problem. Also, certain fundamental functions may be indivisible, and, as already mentioned, we know our ecosystems can experience tipping points - what we think is a small change could lead to non-marginal outcomes. In these once-and-for-all choice circumstances, monetary valuation is stretched beyond its (economic, rational, moral) limits. Farley (2008) suggests that transdisciplinary teams need to be brought together to estimate our position along a trajectory from a situation where changes really are marginal, through a stage where natural capital is declining to the critical thresholds of system collapse. Policy responses might include a reworking of market prices, supply-capping, or a concerted effort at system restoration, respectively.

The language of system collapses sounds hyperbolic, but some UK ecosystems are very vulnerable because of an imbalance in socio-ecological sustainability. In the 5 yr from 1993, UK landscaping and horticulture peat consumption increased from 2.54 million to 3.16 million $\mathrm{m}^{3}$, a $24 \%$ rise (ODPM 1999). Much of this is from lowland peat bogs, but upland peatlands are also subject to perturbation and degradation. About three-quarters of blanket bog habitat designated as Sites of Special Scientific Interest is not in target condition. Yet the predominant deliberations about peatland management now are about whether they will be carbon sinks, or sources (or transient sources, in the case of post-restoration bogs where methane emissions rise on rewetting, until the ecosystem re-equilibrates). This one ecosystem service outweighs all others. Some may feel it needs to, but what is required is robust ecosystem analysis that includes a consideration of the overall 'footprint' of any interventions that are focused just on one perceived benefit of the ecosystem, involving the kinds of multi-scale assessments that Farley (2008) and the EEA (2008) suggest. Scientists really must address the true complexity of the world. To echo Spash \& Vatn (2006), 'where policy makers demand theoretically meaningless numbers, on grounds of pragmatism, they need to be challenged rather than pandered to'.

\section{NEW CHALLENGES}

\subsection{The dynamic environment}

Dynamic processes in the natural world underpinand threaten - the current distribution and composition of ecosystems. Although the issues of a changing world were recognised many years ago (e.g. Mace et al. 1998), conservation, on land and even in oceans, is still substantially static with respect to species and habitat distributions. Progress has been made in recognising the need for more resilient allowance for ecosystem dynamics (e.g. Marine Conservation Zone designations), but a major research challenge still remains in fostering an understanding of dynamic processes in environmental management. The ecosystem services concept is a means of bringing human dynamics into the mix, but it does not simplify the challenges.

With the publication of every new global environmental assessment, a clear message is reinforced. Society has moved into a no-analogue state, with both unprecedented levels and unprecedented rates of environmental change. The complexity of the socio- 
ecological system means that many environmental properties are changing with time. Species assemblages, phenology, organism responses to stressors and many other patterns can no longer be regarded as constant. Assumptions that we could learn from the past to manage the present environment and secure future well-being are being stretched.

This also applies to socio-economic dimensions. Values held or determined in the past may not hold now. From an economics research perspective, there are ways of testing this, of course. Brouwer (2006) has carried out one of very few studies of how contingent values for environmental benefits stand the test of time, investigating the willingness to pay to avoid bathing water quality risks before and after the 2003 heat wave, as well as testing for participants' underlying preferences. While willingness to pay values seemed to be robust, different tests of the simple multivariate model used gave different results, raising the question of what was shaping the underlying preferences. More generally, however, it is difficult to grasp how conceptions of sustainability itself might be changing. The Foresight Future Flooding project (2004) grappled with the question of how adaptive policies might be made resilient across different future scenarios, where social priorities might be very different from today's.

Climate change presents serious threats to UK uplands. Other papers in this special issue explore the threats more fully. The socio-ecological question that is starting to be articulated is: if upland peatlands are facing irreversible decline or 'extinction' as a result of changing temperature and precipitation under already committed climate change, is this actually a means of expanding conservation choice? Does it present new opportunities to do other things with that land, in order to maximise the human or social benefits? From an Earth systems perspective, the current environment is one of many possible states. In a warmer, drier world, uplands would have different species distributions, different community composition and different rates for biogeochemical processes. In Scotland, there is already active deliberation about woodlands policy in peat-rich areas. These choices become sharply focused in the context of a changing environment.

Table 1 shows that there are UK-level socio-ecological reviews of impact assessment of soil erosion, pollinator decline, national-level trace gas emissions (including pollutants) and carbon flux, of which only the latter is specific to moorlands, and none project robustly into the future. The EA/QUEST (Environment Agency/ Quantifying and Understanding the Earth System) activity reported in this special issue of Climate Research is therefore a substantial addition to information about baseline ecosystem function.

\subsection{Models, uncertainty, hubris}

Despite all the calls for more research into ecosystem processes and more environmental data, the information we already have allows us to venture into futurology. While economists and philosophers grapple with questions about the needs and preferences of future generations, Earth system science now promises to provide predictive tools for ecosystem function. So is it just a small 'skip and a jump' to predicting future ecosystem services?

In the last 5 years, several of the world's leading climate models have incorporated modules for dynamic land vegetation, ocean ecosystems and atmospheric chemistry that allow for biosphere-climate interactions to be explored. Climate models (general circulation models, GCMs) have now worked so well-the ones used in the Intergovernmental Panel on Climate Change (IPCC) show significant skill in representing important climate features, consistent with fundamental physical principles and with observations - that there is a growing move towards even greater 'integration'. The inclusion of social and economic processes is needed, so goes the argument, in order to optimise policies that meet the multiple goals of our major global conventions: the Convention on Biological Diversity, the UN Framework Convention on Climate Change and the Millennium Development Goals. Most integrated assessment models (IAMs) link input/output or applied general equilibrium economic models onto simple climate models, in order to assess climate policies, but they too are increasing in complexity. There is an expectation, and in some arenas an expressed desire, that these model types will morph into a fully coupled whole-Earth model. The strategy of the The World Climate Research Programme (2005) states:

It is now possible for the WCRP to address the seamless prediction of the climate system from weekly weather to seasonal, interannual, decadal and centennial climate variations and anthropogenic climate change. Advances in understanding and in new technology for observations and computing also make it possible to contribute to the broader questions of Earth system modelling and the use of comprehensive Earth system models for investigating the habitability of our planet, and contributing to the socio-economic welfare and the sustainability of modern societies and their supporting environments. (p. 5)

The International Geosphere-Biosphere Programme's project Analysis, Integration and Modelling of the Earth System (AIMES) has also set itself a remit of developing predictive Earth system models (AIMES 2009), although it acknowledges that:

Quantitative predictions tend to be both inherently uncertain and potentially misleading because human actions are imperfectly predictable and the structure 
of the societies and economies that drive those actions evolve continuously. Using economic components in a complex global prediction model is therefore a conceivable use, but not the only use (and probably not the most important use) of economics in applied Earth system science. (p. 9)

At the same time, some voices (Demeritt 2001, 2009, Manson 2008) draw attention to the tacit beliefs in statements like these about determinacy, system predictability, rationality and control, not all of which are desirable features in society. In the past, these issues have been enough to rift social sciences apart from both economics and the biophysical sciences (e.g. Harrison et al. 2008). The urgency of environmental problems is bringing new dialogues, however.

Pre-emptive adaptation-i.e. responding to anticipated risks to ecosystem services that model projections forecast-raises enormous new challenges. We do not know how modular our socio-ecological system is, making it difficult to know whether any ecosystem services might be substitutable for any others, or what unanticipated consequences there may be if landscapes and habitats are 'adapted' by human intervention.

Nevertheless, these questions are being articulated and may represent a step-change for ecology and conservation biology. Hobbs et al. (2006) considered the issues surrounding novel ecosystems that arise through human action, either deliberate or inadvertent. In the past, 'synthetic nature' has generally been regarded as less valuable than 'natural' nature and to have reduced functions (e.g. restored peatlands are not as efficient at carbon sequestration as pristine ones and may be methane sources; replanted woodlands have lower biodiversity than wild woods; artificial wetlands tend to support fewer bird species). But, if in the future, natural nature is expected to experience adverse climate impacts, then that difference may not remain (McKibben 2003). Furthermore, a human-created ecosystem might be optimised for the future. Species could be introduced or swapped to ensure continuity of ecosystem function, in order to maintain the benefits to people. The instrumentalism embedded in the ecosystem services concept might mean that these would be the applications of future functional assessments of ecosystems.

Williams \& Jackson (2007) bring a palaeo-ecological perspective to bear on this issue, pointing out that the no-analogue climate conditions we are entering could well lead to no-analogue ecosystems. The more we move into this uncharted climatic territory, even if we are equipped with the best possible Earth system models, the less equipped we will be with our current understanding of ecological processes and patterns. Williams and Jackson argue that the risk of ecological surprises ahead, with a corresponding loss of ecosys- tem services in a warmer world, should motivate us to keep climate within the range of predictability, at the least.

\subsection{Interdisciplinarity}

Integrating natural science, economics and social science is difficult, but crucial. As a research community we have made enormous progress in that integration. Ecosystem services has already engaged a very diverse community and generated a great deal of interdisciplinary dialogue, but, as already indicated, much more is needed.

The challenges of working across knowledge communities should not be underestimated, but neither should the rewards (Nissani 1997). Liverman \& Roman-Cuesta (2008) call for a greater level of tolerance and mutual understanding, especially at the interfaces between qualitative and quantitative research traditions in order to develop better theories of human interaction with the land that will work in the context of changing climate and other global change pressures. Spash \& Vatn (2006) argue that economic valuation is evidently an interdisciplinary undertaking linking natural science with social science, and, as a result, 'a full range of perspectives on human behaviour is required'. This would be novel information for most natural scientists.

Deep integration of this kind raises new questions of rigour and methodology, and I consider that it needs reflexivity (Stirling 2006, Lowe \& Phillipson 2006). People engaged in producing transdisciplinary research must take time to articulate their worldviews and think about how they shape their research actions and directions. This is perhaps even more important for those who are engaging with communities and policy-makers. Knowledge shared in these contexts can definitely no longer be regarded as a theoretical abstraction.

So ecosystem services - the concept-brings many scholars from a 'detached', 'value-neutral' academic starting point to the realization that they should recognize and then grapple with the questions of ethics, moral philosophy and philosophy of science that are seen by many natural and physical scientists as the preserve of eccentrics and boffins. Unfortunately, most normal scientific and economic educations do not equip scholars with the intellectual tools of these trades. The social sciences, however, have a stronger tradition of reflexivity. They engage in the intellectual discipline of disambiguating the methodological and epistemological framing of their work from their own views of how the world is (the ontological aspects of their work). They could provide some direction in this new territory. 


\section{OUTLOOK AND RECOMMENDATIONS}

The ecosystem services concept has spawned a very substantial policy framework and highlighted a shortage of underpinning evidence. Values of part-services do not sum to the whole value. There is a serious scarcity of valuation data; and the nature of the connections between ecosystem process, function, integrity and benefits requires a step change in conceptualization.

On the bright side, there is a great deal of discussion now, in the academic literature and in face-to-face meetings around the world, involving scholars from various disciplines in academia, business and the public sector. The concept is evolving, as well as new tools for ecosystem service mapping, accounting andwhether we like it or not-prediction.

A focus on certain meta-debates should be raised alongside the rising visibility of the concept itself. First a research concept so tightly knitted into policy requires thought about the nature of the science-policy engagement and not just by the individuals actually working at that interface. Research in this burgeoning field may well be applied in the real world. Experience with benefits transfer tells us that we do not know how our knowledge may be used; it also reminds us that it might be misapplied. And thus secondly there is a concomitant need for a greater literacy in research ethics among scientists as well as in the wider community.

In the UK, the EA/QUEST uplands project has brought an interdisciplinary community together, linking ecosystem scientists, natural resource managers and climate researchers to explore the future of UK uplands and peatlands. The joint ESRC-NERC (Economic and Social Research Council-Natural Environment Research Council) transdisciplinary workshop series $^{\underline{2}}$ have provided a forum for the ecosystem services research community, where ideas and networks have matured. They have supplied opportunity for the gritty discussions that are urgently needed about the purpose, scope, tacit assumptions, shortcomings and forward challenges of the ecosystem services concept. These were time-limited activities, however. Sustained support is needed for these dialogues.

Since many of our ecosystem services are global, international research and policy connectivity are important. Case studies should be shared across and beyond the narrow discipline domains of ecology or environmental economics. The Ecosystem Services Partnership (www.ecosystemservicespartnership.org) offers a new international forum for information sharing and dialogue among academics, policy people and

${ }^{2}$ The final event in the series, in September 2009, was a synthesis of all 7 series (www.nottingham.ac.uk/fresh/ seminarsix.html) practitioners. It has links to the International Society for Ecological Economics, an academic society, and to the Nature Valuation and Financing Network (www. fsd.nl/naturevaluation), which is focused on the development and exchange of practical tools and on case studies. These institutional support structures certainly need to evolve and mature, but they have been created with an inclusive and deliberative ethos that should enable them to evolve positively.

Acknowledgements. This work was supported by the UK Natural Environment Research Council through QUEST (Quantifying and Understanding the Earth System), and by NERC's directed programme for Earth System Science, and it benefited from discussions with Harriet Orr, Bridget Emmett, Sue White, William Watts, Anna Maria Giacomello, all linked to the EA/QUEST soil project, and with Ian Bateman and Kerry Turner. The constructive comments of the anonymous reviewers improved the present study and, above all, indicate that there are some very interesting debates still to be had in this area.

\section{LITERATURE CITED}

AEA Technology (2005) Damages per tonne emission of $\mathrm{PM}_{2.5}, \mathrm{NH}_{3}, \mathrm{SO}_{2}, \mathrm{NO}_{\mathrm{x}}$ and VOCs from each EU25 Member State (excluding Cyprus) and surrounding areas. Service contract for carrying out Cost-Benefit Analysis of air quality related issues in particular in the Clean Air for Europe (CAFÉ) programme. AEA Technology Environment, Didcot. www.cafe-cba.org/assets/marginal_damage_03-05.pdf (accessed 18 March 2010)

AIMES (Analysis, Integration and Modeling of the Earth System) (2009) AIMES science plan (Draft). IGBP Report 58, IGBP Secretariat, Stockholm

Allen-Wardell G, Bernhardt P, Bitner R, Burquez A and others (1998) The potential consequences of pollinator declines on the conservation of biodiversity and stability of food crop yields. Conserv Biol 12:8-17

Anderies JM, Janssen MA, Ostrom E (2004) A framework to analyze the robustness of social-ecological systems from an institutional perspective. Ecol Soc 9:18. Available at: www.ecologyandsociety.org/vol9/iss1/art18/

$>$ Bateman IJ, Lovett AA (2000) Estimating and valuing the carbon sequestered in softwood and hardwood trees, timber products and forest soils in Wales. J Environ Manag 60: 301-323

> Bateman IJ, Langford IH, Willis KG, Turner RK, Garrod GD (1995) The impacts of changing willingness-to-pay question format in contingent valuation studies: an analysis of open-ended, iterative bidding and dichotomous choice formats. Ecol Econ 12:161-179

> Bennett RM, Tranter RB, Blaney RJP (2003) The value of countryside access: a contingent valuation survey of visitors to the Ridgeway National Trail in the United Kingdom. J Environ Plann Manage 46:659-671

Boiesen J, Jacobsen JB, Thorsen BJ, Strange N, Dubgaard A (2005) Valuation of Danish moorland (Værdisæetning af de danske lyngheder). Report for the Forest and Nature Agency, Denmark. Forest \& Landscape Working Paper No. 14-2004, KVL, Frederiksberg

Boyd J, Banzhaf S (2007) What are ecosystem services? Ecol Econ 63:616-626 
Boyle KJ, Bergstrom JC (1992) Benefit transfer studies: myths, pragmatism, and idealism. Water Resour Res 28:657-663

Boyle KJ, Bishop RC, Welsh MP (1985) Starting point bias in contingent valuation surveys. Land Econ 61:188-194

Brander LM, Florax RJGM, Vermaat JE (2006) The empirics of wetland valuation: a comprehensive summary and a meta-analysis of the literature. Environ Resour Econ 33: 223-250

Brookshire DS, Neill HR (eds) (1992) Benefit transfers: conceptual and empirical issues. Water Resour Res 28:651-655

Brouwer R (2006) Do stated preference methods stand the test of time? A test of the stability of contingent values and models for health risks after an extreme event. Ecol Econ 60:399-406

Brouwer R, Spaninks FA (1999) The validity of environmental benefits transfer: further empirical testing. Environ Resour Econ 14:95-117

Brown JR, MacLeod ND (1996) Integrating ecology into natural resource management policy. Environ Manag 20: 289-296

Bullock CH, Kay J (1997) Preservation and change in the upland landscape: the public benefits of grazing management. J Environ Plann Manag 40:315-334

Christie M, Matthews J (2003) The economic and social value of walking in England. Report for the Ramblers' Association. Available at: www.ramblers.org.uk/info/factsandfigures/references.htm (accessed 13 December 2009)

Colombo S, Calatrava-Requena J, Hanley N (2006) Analysing the social benefits of soil conservation measures using stated preference methods. Ecol Econ 58:850-861

Costanza R (2008) Ecosystem services: multiple classification systems are needed. Biol Conserv 141:350-352

Costanza R, Daly HE (1992) Natural capital and sustainable development. Conserv Biol 6:37-46

Costanza R, d'Arge R, de Groot R, Farber S and others (1997) The value of the world's ecosystem services and natural capital. Nature 387:253-260

Daily GC (ed) (1997) Nature's services: societal dependence on natural ecosystems. Island Press, Washington, DC

Daly H (1986) Toward a new economic model. Bull At Sci 42:42-44

Daly H (2009) Three anathemas on limiting economic growth. Conserv Biol 23:252-253

Defra (Department for Environment, Food and Rural Affairs) (2007) Securing a healthy natural environment: an action plan for embedding an ecosystems approach. UK Government Defra. Available at: www.defra.gov.uk/wildlifepets/policy/natural-environ/documents/eco-actionplan.pdf (accessed 8 March 2010)

Demeritt D (2001) The construction of global warming and the politics of science. Ann Assoc Am Geogr 91:307-337

> Demeritt D (2009) Geography and the promise of integrative environmental research. Geoforum 40:127-129

Dickie I, Hughes J, Esteban A (2006) Watched like never before...the local economic benefits of spectacular bird species. RSPB Report. Available at: www.rspb.org.uk/ Images/watchedlikeneverbefore_tcm9-133081.pdf (accessed 13 December 2009)

Eftec (Economics for the Environment Consultancy) (2006) Valuing our natural environment. Final report, Defra Research Project NR0103, Department for Environment, Food and Rural Affairs, London. Available at: http://randd.defra.gov.uk/Default.aspx?Menu=Menu\& Module $=$ ProjectList $\&$ Completed $=0 \&$ FOSID $=38$ (accessed 18 March 2010)

Ehrlich PR, Ehrlich AH (1992) The value of biodiversity. Ambio 21:219-226
Ehrlich PR, Mooney HA (1983) Extinction, substitution, and ecosystem services. Bioscience 33:248-254

English Nature (2006) England's ecosystem services. A preliminary assessment of three habitat types: broad-leaved woodland, the inter-tidal zone and fresh-water wetlands. English Nature Research Reports 701. Available at: http://naturalengland.etraderstores.com/NaturalEngland Shop/R701 (accessed 13 December 2009)

EPFI (Equator Principles Financial Institution) (2006) The 'Equator Principles': a financial industry benchmark for determining, assessing and managing social and environmental risk in project financing. Available at: www. equator-principles.com/principles.shtml (accessed 13 December 2009)

European Environment Agency (2008) Ecosystem services: accounting for what matters. EEA Briefing 2/2008. Available at: www.eea.europa.eu/publications/briefing_2008_2 (accessed 24 November 2009)

Farley J (2008) Valuing natural capital: the limits of complex valuation in complex systems. In: Economics and conservation in the tropics: a strategic dialogue. Available at: www. rff.org/Documents/08_Tropics_Conference/Tropics_ Conference_Papers/Tropics_Conference_Farley_Valuing_ Natural_Capital.pdf (accessed 21 October 2009)

> Fisher B, Turner RK (2008) Ecosystem services: classification for valuation. Biol Conserv 141:1167-1169

> Fromm O (2000) Ecological structure and functions of biodiversity as elements of its total economic value. Environ Resour Econ 16:303-328

> Garrod GD, Willis KG, Saunders CM (1994) The benefits and costs of the Somerset levels and moors ESA. J Rural Stud 10:131-145

Ghermandi A, van den Bergh JCJM, Brander LM, de Groot HLF, Nunes, PALD (2008) The economic value of wetland conservation and creation: a meta-analysis. Working Paper 79, Fondazione Eni Enrico Mattei, Milan

Graves A, Morris J, Chatterton J, Angus A, Harris J, Potschin M, Haines-Young R (2009) Valuation of natural resources-a NERC scoping study. Scoping Study 2, Final report. Available at: www.nerc.ac.uk/research/themes/tap/ reports/2008/documents/scoping-study2.pdf (accessed 13 December 2009)

Gren IM, Folke C, Turner K, Bateman I (1994) Primary and secondary values of wetland ecosystems. Environ Resour Econ 4:55-74

Harrison S, Massey D, Richards K (2008) Conversations across the divide. Geoforum 39:549-551

Hobbs RJ, Arico S, Aronson J, Baron JS and others (2006) Novel ecosystems: theoretical and management aspects of the new ecological world order. Glob Ecol Biogeogr 15: $1-7$

HM Government (2005) Securing the future: delivering UK sustainable development strategy. TSO (The Stationery Office), Norwich. Available at: www.defra.gov.uk/sustainable/ government/publications/uk-strategy/ (accessed 13 December 2009)

IPCC (Intergovernmental Panel on Climate Change) (2007) Impacts, adaptation and vulnerability. In: Parry ML, Canziani OF, Palutikof JP, van der Linden PJ, Hanson CE (eds) Contribution of Working Group II to the 4th Assessment Report of the Intergovernmental Panel on Climate Change. Cambridge University Press, Cambridge

Jacobs Consultancy Ltd. (2008) Valuing England's terrestrial ecosystem services. Final Report. Defra Research Project NR0108. Available at: http://randd.defra.gov.uk/Document. aspx?Document=NR0108_7324_FRA.pdf (accessed 13 December 2009) 
Janssen R, Van Herwijnen M (2006) A toolbox for multicriteria decision-making. Int J Environ Technol Manage 6: 20-39

Kant I (1998) Groundwork of the metaphysics of morals (Gregor $M$ translation). Cambridge University Press, Cambridge

> Liverman DM, Roman Cuesta RM (2008) Human interactions with the Earth system: people and pixels revisited. Earth Surf Process Landf 33:1458-1471

Loomis JB, Rosenberger RS (2006) Reducing barriers in future benefit transfers: needed improvements in primary study design and reporting. Ecol Econ 60:343-350

Lowe P, Philllipson J (2006) Reflexive interdisciplinary research: the making of a research programme on the rural economy and land use. J Agric Econ 57:165-184

Lucas K, Walker G, Eames M, Fay H, Poustie M (2004) Environment and social justice: rapid research and evidence review. Sustainable Development Research Network, Policy Studies Institute, London

Mace GM, Balmford A, Ginsberg JR (eds) (1998) Conservation in a changing world. Conservation Biology Series 1. Cambridge University Press, Cambridge

Manson SM (2008) Does scale exist? An epistemological scale continuum for complex human-environment systems. Geoforum 39:776-788

McHugh M (2003) Soil erosion in the UK: assessing the impacts and developing indicators. OECD Expert Meeting on Soil Erosion and Soil Biodiversity Indicators. Rome, March 2003. http://webdomino1.oecd.org/comnet/agr/soil_ ero_bio.nsf (accessed 18 March 2010)

McKibben WE (2003) The end of nature, 2nd edn. Bloomsbury, London

MA (Millennium Ecosystem Assessment) (2005) Ecosystems and human wellbeing: synthesis. Island Press, Washington, DC

MFTF (Moors for the Future Partnership) (2007) Peak District moorland: carbon flux. Moors for the Future Research Note No 12. www.moorsforthefuture.org.uk/mftf/downloads/ publications/MFF_researchnote12_carbonflux.pdf (accessed 18 March 2010)

> Nissani M (1997) Ten cheers for interdisciplinarity: the case for interdisciplinary knowledge and research. Soc Sci J 34: 201-216

ODPM (Office of the Deputy Prime Minister) (1999) Peatland issues: report of the Working Group on Peat Extraction and Related Matters. Available at: www.communities. gov.uk/archived/publications/planningandbuilding/ peatlandissuesreport (accessed 1 November 2009)

Pearce D (2002) An intellectual history of environmental economics. Annu Rev Energy Environ 27:57-81

Pearce D, Barrett S, Markandya A, Barbier E, Turner RK, Swanson T (1996) Blueprint 2: greening the world economy. Earthscan, London

Raffaelli D, Smart J, Austen M, Mangi S and others (2009) Valuation of biodiversity-a NERC scoping study. Scoping Study 1, Final Report. UK Natural Environment Research Council, Swindon. Available at: www.nerc.ac.uk/ research/themes/tap/reports/2008/documents/scopingstudy1.pdf. (accessed 13 December 2009)

Sagoff M (2000) Environmental economics and the conflation of value and benefit. Environ Sci Technol 34:1426-1432

Sinden A (2004) The economics of endangered species: why less is more in the economic analysis of critical habitat designations. HELR Harvard Environ Law Rev 28: 129-214

Spash CL, Vatn A (2006) Transferring environmental value estimates: issues and alternatives. Ecol Econ 60:379-388
Stern DI (1999) Use value, exchange value, and resource scarcity. Energy Policy 27:469-476

Stirling A (1997) Multicriteria mapping: mitigating the problems of environmental valuation? In: Foster J (ed) Valuing nature: economics, ethics and environment. Routledge, London, p 186-210

Stirling A (2006) Precaution, foresight, and sustainability: reflection and reflexivity in the governance of science and technology. In: Voss JP, Bauknecht D, Kemp R (eds) Reflexive governance for sustainable development. Elgar, Cheltenham

Stirling A, Gee D (2002) Science, precaution, and practice. Public Health Rep 117:521-533

Sukhdev P (ed) (2008) The economics of ecosystems and biodiversity. The TEEB interim report. Available at: www. teebweb.org/LinkClick.aspx?fileticket=5y_qRGJPOao $\%$ 3d\&tabid=1018\&language=en-US (accessed 13 December 2009)

ten Brink P, Berghöfer A, Schröter-Schlaack C, Sukhdev P, Vakrou A, White S, Wittmar H (2009) The economics of ecosystems and biodiversity for national and international policy makers: summary. Available at: www.teebweb.org/ LinkClick.aspx? fileticket=I4Y2nqqIiCg \%3d\&tabid=924\& language=en-US (accessed 13 December 2009)

The World Climate Research Programme (2005) WCRP strategic framework 2005-2015. Coordinated Observation and Prediction of the Earth System (COPES). WCRP-123, WMO/TD-No. 1291, The World Climate Research Programme, Geneva http://www.wmo.ch/pages/prog/wcrp/ pdf/WCRP_strategImple_LowRes.pdf

Turner RK (1992) Speculations on weak and strong sustainability. CSERGE Working Paper, gec-1992-26. Centre for Social and Economic Research on the Global Environment, University of East Anglia, Norwich

Turner RK, Daily GC (2008) The ecosystem services framework and natural capital conservation. Environ Resour Econ 39:25-35

United Nations Development Programme (2007) Human Development Report 2007/2008: fighting climate change. Available at: hdr.undp.org/en/reports/global/hdr2007-2008 (accessed 13 December 2009)

United Nations Environment Programme (2007) Global Environment Outlook 4 (GEO4): environment for development. Available at: www.unep.org/geo/geo4/media/ (accessed 13 December 2009)

Vandermeer J, Lin BB (2008) The importance of matrix quality in fragmented landscapes: understanding ecosystem collapse through a combination of deterministic and stochastic forces. Ecol Complex 5:222-227

von Mises L (1996) Human action: a treatise on economics, 4th edn. Foundation for Economic Education, Irvington, NY

Walker GP (2007) Environmental justice and the distributional deficit in policy appraisal in the UK. Environ Res Lett 2:045004. doi:10.1088/1748-9326/2/4/045004

Wallace KJ (2007) Classification of ecosystem services: problems and solutions. Biol Conserv 139:235-246

- White PCL, Lovett JC (1999) Public preference and willingness-to-pay for nature conservation in North York Moors National Park, UK. J Environ Manage 55:1-13

Williams E, Firn JR, Kind V, Roberts M, McGlashan D (2003) The value of Scotland's ecosystem services and natural capital. Eur Environ 13:67-78

Williams JW, Jackson ST (2007) Novel climates, no-analog plant communities, and ecological surprises: past and future. Front Ecol Environ 5: 475-482

Woodward RT, Wui YS (2001) The economic value of wetland services: a meta-analysis. Ecol Econ 37:257-270 